\title{
Mapping The Strategy Of Development Of The Creative Economy South Tangerang- Based Prospective Analysis
}

\author{
Nur Aini \\ Program Studi Manajemen, Institu Teknologi dan Bisnis Ahmad Dahlan Jakarta \\ *Coresponding Author \\ E-mail: aini.nur1969@gmail.com
}

\begin{abstract}
The creative economy is one of the boosters in spurring economic development in South Tangerang City. Activities that support economic growth where production, distribution and consumption become a unified chain that is interconnected between creative economic actors, distribution chains, consumers and the government as regulator. The purpose of this study is to map the strategic development of a creative economy based on prospective analysis in South Tangerang. The primary data collection method was done by interview and direct observation to the field. Secondary data collection was taken from literature review. Analysis of data used prospective analysis. The results showed that the average star up did not have legality, consequently access to capital was difficult. Capital and product development are variables that have a very strong dependency and influence in the development of the creative economy, and which are included in this output variable are processing facilities, availability of raw materials, employment, revenue, packaging, shelf life, business meeting. Suggestions that can be given related to the results of this research are the socialization of legality management needs to be improved and the need for training according to the creative economy business category in South Tangerang.
\end{abstract}

Keywords: UKM, Access Capitalization, Legality, Product Development, Packaging

\section{INTRODUCTION}

The creative economy is predicted to be one of the sectors that can boost the growth of the Indonesian economy in the future. Some publications of the Creative Economy Agency (BEKRAF) in collaboration with the Central Statistics Agency (BPS) confirms that the development of creative economy in Indonesia showed a positive trend. In 2016, the GDP of the creative economy grew by 4.95 per cent compared to 2015 , while exports of the creative economy grew to $3.23 \%$. Subsector of the creative economy with biggest revenues in 2016 is culinary $(41,4 \%)$, fashion $(18,01 \%)$, and kriya $(15,4 \%)$.

Along with the development of Indonesia's economic growth jacked by the development of the creative economy, South Tangerang City also has a huge potential in the sector of food, fashion and craft. There are 8.2 million businesses engaged in the sector of the economy (Economic Census 2016). The potential of this great, dikatalis by a local government on relevant agencies to advance the culinary industry, fashion and craft. Sub-sector konomi creative is believed to reduce inequality gini ratio between the region of Jakarta as the capital city with the surrounding region.

In addition, $96 \%$ of the creative economy is in the informal sector located in the City of South Tangerang, even just $1 \%$ in the form of business entity limited liability company (PT). This Data can be used as a basis for making policy for the creative economy in the future. In addition, the data diharapjan also can be a reference for evaluation of the effectiveness of programs that have been implemented and will be initiated by the various interests of the City of South Tangerang. 
In the era of knowledge economy, as now, the power of ideas or creative ideas can not be considered playful. No less than the innovation expert renowned Canton (2007) suggested that $1 / 3$ of global GDP today comes from the so-called creative industries. In addition, the creative industries are considered as a future industry that can sustain the world of kala hit by the global crisis due to the movements of the wild the instruments of the paper is both complicated like an instrument securities and derivatives.

Thus, the presence of what is called the centers of the creative industry actually is undoubtedly. Therefore, creativity is indeed ought not to be treated as a luxuriance of inspiration alone. On the contrary, creativity is to be managed and institutionalized, such as through the format of the creative industries, to be more focused and more efficient. In short, in order to be effective. Therefore, it is time for Indonesia to start the work to build the pockets of the industrial center or the creative economy in the country. Florida (2004) said that innovation or creativity in the region can only grow lush or explosive if that region has three $\mathrm{T}$ : tolerance (tolerance), technology (technology), and talent (talented human resources).

Based on this, the project is a creative industry must pay attention to three aspects. First, tolerance. I mean, the region where the center of the creative industries that will be established should have the characteristics of a community that is tolerant of ideas that are new, different, and even controversial. Therefore, a suitable location is the place that the characteristics of the communities are not homogeneous, both in terms of ethnicity, religion, race, class, or thinking. With a location like this, the risk of intolerance can be minimized and the potential for tolerance is maximized. Second, technology. The center of the creative industries it should ideally have the support technology to help the embodiment of creative ideas into one products concrete that can be thrown into the market for the sake of scoring big profits. Hence, the need to think of stimulation in order to bring the technology needed. For example, if there is technology that can't be produced by the domestic industry and have to be imported, the government can provide incentives free of customs duty (import duty) for the technology that will be used in the center or the heart of the creative industries. Incentives like these are certainly lighten the load as well as excite the creative companies that operate in the region.

Third, talent or human resources (HR). The center of the creative industries must have a talented HR superior and has a variety of brilliant minds from various fields of science. Therefore, in the era of globalization this is a specialization of science becoming blurred. As revealed Pangestu (2008), the 21st century is the era of thought intersection (intersectional) where a meeting of the various currents of thought brilliantly boils down to one of the remarkable innovations.

From this perspective, for example, the film industry requires not only human resources graduate film school alone, but also requires human resources from other fields, such as history to help the accuracy of the scenario for example. Therefore, the center of the creative industries will be established preferably consists of industries that employ human resources are heterogeneous for the achievement of intersectional innovation which is awesome. For example, there is one branch of Indonesia from the digital company the leading global employs a lot of people from the disciplines of the humanities for the sake of giving a perspective that is more humane to the product of their automated.

In the current era of globalization the development of the business world is growing very rapidly, one in the field of culinary business. This business-related needs of human food. Food is one of the basic human needs or basic needs. Because it includes basic needs, then the fulfillment of food into absolute terms for humans who want to keep the continuity of his life. Human activity is currently one was so dense as lead man looking for a practical way to meet the needs of food. As for the way in which to meet the food needs of one of them by utilizing the services of the food. 
Food is no longer consumable products to meet the biological needs of human beings alone. Food is becoming a new lifestyle in the society. Food turned into a culinary industry which gives not only the taste but also the needs of other people to socialize and actualization (Winarno 1990). Therefore, the culinary industry developed at this time also provides a space for consumers to be able to gather with the community through service and other services.

"It is not surprising if the culinary industry is currently growing very fertile. There are a few things that indicate that. It is at least evident from the pattern of consumption that began to shift to the cuisine and drink so. In 2006 when the roadmap of the creative industries.

According to the theory of Maslow's hierarchy of needs, food is one of the basic human needs or basic needs. Because it includes basic needs, then the fulfillment of the food to be an absolute thing if people want to keep the sustainability of life. After basic needs are met, the new man will could think of to reach the other needs. The need to socialize (social needs), confidence (self esteem) and self-actualization (self-actualization) are the three top human needs.

The ministry of Tourism and Creative Economy in 2011 enter the food as one of the subsector of the creative economy. Culinary basically closely related to the process in preparing food or cooking that is the basic activities of the human meet the needs of life. The term culinary in Indonesia began to be the talk of society in 2005 after the program television's "Culinary", covering places to eat unique or already have a good reputation become a favorite spectacle of Indonesian society.

Culinary subsector provide a substantial contribution, which is 30 percent of the total revenue of the tourism sector and the creative economy. The culinary industry has a potential that is very powerful for developing, therefore, the government will support the sub-sector to make it more advanced.

Some of the perpetrators of the culinary industry to see there are some things, which should be corrected and managed more serious. One of them is the need to access business licensing through one of the doors so it is more easy and effective. The culinary businesses new you should get guidance from the government, could be from business training, licensing information, up on the legal assistance in the process of business establishment.

One of the pendevinisian culinary mention as preparation, processing, and presentation of food and beverage products that combine elements of creativity, aesthetics, tradition, and/or local knowledge. The four elements are important in improving the taste and value of food products to pull resources buy and gives the "impression" for consumers. From the above definition, there are some keywords, i.e. creativity, aesthetics, tradition, and local wisdom.

Creativity.

Creativity is meant is the aspect of new ideas either through the recipe creations, the creation of a way of processing, and the creation of a way of presentation that add value to the food and drinks. The process of creativity should not always produce something 100 percent new, but can in the form of development of something that already exists so that the value is higher and more attractive in the market.

Aesthetic.

Aesthetic referred to is the aspect of the appearance of a food and beverage attention to the beauty that makes culinary products that have more value and able to arouse the taste of the consumer to enjoy it.

Tradition.

The tradition in question is something that has been done since a long time and become part of the lives of a group of people related to the habit in processing and consumption of food and drinks. The most fundamental thing of tradition is the presence of information that is transmitted from generation to generation both written and oral, because in the absence of this 
process, a tradition can be extinct. Elements of this tradition is very important in maintaining the cultural heritage of Indonesian culinary.

\section{Local Wisdom.}

Local wisdom that question is the identity of an area in the form of truth that has been embedded in an area. With regard to food, local wisdom is the wisdom of the man who leaned on the philosophy of values, ethics, ways, and behavior. institutionalized traditionally, will form the culinary character of an area. Culinary character must be able to be raised and introduced to the public.

The scope of the sub-sectors of the food in Indonesia is divided into two main categories if, in terms of the type of products offered, namely culinary services and goods culinary. Culinary services (food service) is reviewed from the aspects of preparation and presentation, can be divided into two general categories, i.e. restaurants and catering services. While the item culinary question is the food products processed or packaging, especially in the category of specialty foods. Product special food is growing at this time (Winarno 1990).

In general, specialty foods produced in an amount of not too large and the product has its own uniqueness that require creativity in its creation. Some of the products included in this category are food products that use organic ingredients or raw materials typical of an area which is then packaged in a draw. Cultural values and the local content of a region also became one of the sources of the uniqueness of this type of product, such as by the typical food of a region.

The sharpening of the scope of food in the context of the creative economy is a very important thing to do. The focus of the development of SMES in the field of culinary in the City of South Tangerang in the last two years is to advance the items culinary (as shown in figure 1 below) that is self-sufficient.

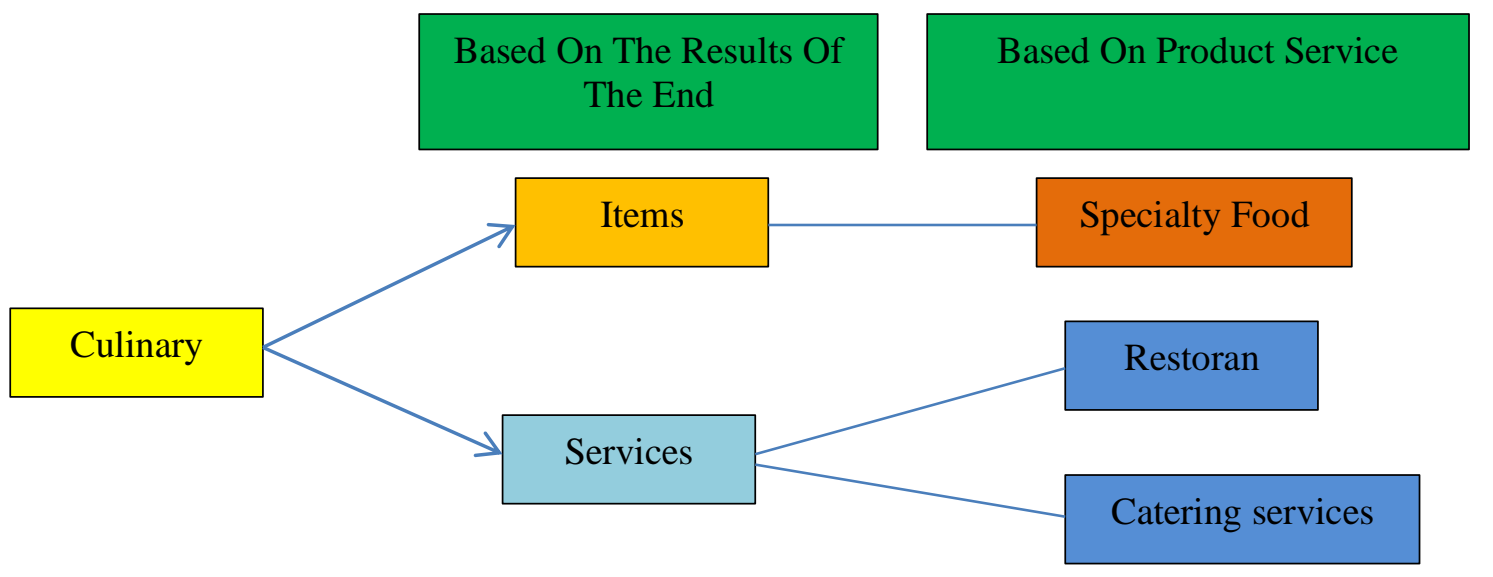

The Focus Of The

Development Prospects Of

Culinary

Figure 1 the Scope and Focus of the Prospects of Development of the Creative Economy the Culinary Field 


\section{Micro, Small and Middle Enterprises (UMKM)}

MSME stands for Micro, Small and Medium-sized businesses. So SMES consists of three forms of business based on its scale, which includes; Micro, Small and Medium-sized Businesses. The following is the understanding of all three is based Legislation:

a. Micro business is a productive business belonging to natural persons and/or entities of individual businesses that meet the criteria of Micro Enterprises as stipulated in this Law. Criteria of assets: a Maximum of 50 Million, the criteria of Turnover: a Maximum of 300 million dollars.

b. Small business is a productive economic business a stand-alone, which is carried out by the individual or business entity that is not a subsidiary or not a branch of a company owned, controlled, or be a part either directly or indirectly from a medium or large business that meets the criteria of a Small Business as referred to in this Law. The criteria of assets: 50 million -500 million, the criteria of Turnover: 300 million to 2.5 Billion dollars.

c. Medium-sized businesses is the business of a productive economy that stands on its own, which is carried out by an individual or business entity that is not a subsidiary or branch of a company owned, controlled, or be a part either directly or indirectly, with a Small Business or a large business with the amount of net assets or the results of the annual sales as regulated in this Law. The criteria of asset: 500 million - 10 Billion, the criteria of Turnover: >2.5 Billion-50 Billion rupiah (UU No. 20 Tahun 2008).

UMKM have their own characteristics that are different with the company's large-scale. They generally have the character of self without having the benefit, or under the auspices of a group of businesses. Other characteristics of the UMKM are using a low tech or simple, even micro businesses often use technology manual. They only use the equipment for what it is, and only produce a few kilos, and net profit was still under the Rp. 30.000,- per day. The uniqueness of SMES compared with companies large-scale, i.e. a narrower market share.

The orientation is only focused on the local market or surrounding locations. Venture capital UMKM is very limited and access to capital is also relatively hard to come by, but they in general are also very in need of capital to expand its business. They need a lot of materials and tools able to increase the amount of a commodity that they produce. Some of the advantages provide capital to the UMKM sector is;

1. Human factor is the important thing to note. That UMKM (Micro, Small, and Medium enterprises) in general is a party that really need the help of capital and should be given more attention intensive.

2. They move in the real field, either in the form of goods or services. The loan that they need not to non-real, as speculation the stock exchange. The financing of the real sector is very important, because the sector is the wealth of the country in the real sense.

3. UMKM managers in general are still based on business ethics and morality. They generally have more respect for the contract (agreement) lending and borrowing than is generally large employers.

The problems of capital SMES is that access to capital is relatively difficult to be done by small businesses or micro, due to several things, among others:

1. System administration of the bank that is convoluted and requires the best that is commensurate with the money lent. 
2. Small businesses in general are a group of grass-roots of society who are less familiar with the language-the language of technical banking. This is where the role of islamic financial institutions in the future, namely the ability to reach out to the community under the absence of the mechanism of the terms that are too heavy and language that is easily understood.

The Prospect Of The Creative Economy

According to Winarno (1990) that the culinary business in Indonesia into class business safe. This is the one that triggers the increasing number of entrepreneurs who cultivate the culinary world of this. He also added, "the culinary Business is so promising because all people need to eat. But, serves food just is not enough so that the necessary ability of the other. This business is very important because it can improve the local economy, though it enters into the realm of culinary home."

With the development of time, the culinary business is not only presented in a conventional, but now many businessmen food that penetrated the online world with the aim of facilitating the range of different types of consumers. Parama Indonesia, an institution pengakomodasi startup company suggested a data, that the culinary sector in Indonesia grew by an average of 7 to 14 per cent per year in the last five years.

Culinary business is increasingly driven by the needs of the community in large cities are increasing. In addition to these factors, the pattern of community life that has the tendency to work until the evening, making them more often order food for delivery rather than eat at home. Moreover, such behavior is supported by the development of technology that allows for us to order food through the internet network.

The habit that finally seen a variety of entrepreneurs as a promising opportunity. No responsibility-responsibility, advantages that can be achieved a culinary business online can reach tens to hundreds of millions of dollars. The agency Indonesia's Creative Economy (Bekraf) also noted the same thing, that the business of Indonesian culinary give the largest contribution to the creative economy sector, followed by other sectors such as fashion, and crafts.

\section{RESEARCH METHODS}

The method used in this research is a survey to know more things in-depth. Methods of primary data collection is done by interview and direct observation to the field. The interview is a process of question and answer with the speaker as well as exchange information and ideas so that the information is accurate (Nasir, 2005). The collection of secondary data taken from the literature review. The analysis of data processing using a prospective analysis.

Analysis of the prospective is one of the techniques to analyze a variety of strategies that can happen in the future based on the conditions that exist today. Analisi prospective also known as needs analysis. Needs analysis is a beginning in the study of a system (Eriyatno 1999). The purpose of the analysis prospective adalan prepare a strategy changes are needed in the future. Approach prospective emphasizes on the process of the evolution of the long-term so that time becomes a factor that is very important in making a decision. 


\section{RESULTS AND DISCUSSION}

This method is based on a doubling of the matrix is square (a matrix with number of rows and columns are the same) - ranking one in the several stages of the iteration to compose the hierarchy of the variables. The analysis of the system variables is done based on the classification directly where the relationship between variables obtained directly from the results of the identification of experts and stakeholders.

Variables are distinguished on the influence variable and variable dependence as well as take into account the distance and the feedback of each variable against other variables. The identification of the relationship between variables is done by using the data category of the scale of the tiered showing the intensity of the relationship.

Table 1 Matrix of Variables that Affect

\begin{tabular}{|c|c|c|c|c|c|c|c|c|c|c|c|c|c|c|}
\hline $\begin{array}{cc}\downarrow & \rightarrow \\
\text { DARI } & \text { THDP }\end{array}$ & $\begin{array}{l}\text { Aksesabilitas } \\
\text { Infrastraktur }\end{array}$ & Pemodalan & $\begin{array}{l}\text { Ketersediaan } \\
\text { Bahan Baku }\end{array}$ & $\begin{array}{l}\text { Tekrikik dan } \\
\text { Sarana } \\
\text { Pengogalana }\end{array}$ & $\begin{array}{l}\text { Penembanangan } \\
\text { Varasis Produk }\end{array}$ & $\begin{array}{l}\text { Unur Simpan } \\
\text { Produlk }\end{array}$ & $\begin{array}{l}\text { Pengemanampac } \\
\text { kaging }\end{array}$ & $\begin{array}{l}\text { CSistem } \\
\text { Pennasaran }\end{array}$ & Pemblukan & TemuB Bisis & $\begin{array}{l}\text { Responsibitias } \\
\text { Linghnongan }\end{array}$ & Ketengagkerjan & Inerizinan Vsaha & $\begin{array}{l}\text { aemingkatan } \\
\text { Onsist }\end{array}$ \\
\hline 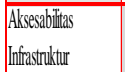 & & 1 & 2 & . & . & . & . & . & . & . & 2 & 1 & . & 1 \\
\hline Pemmodahn & . & & 3 & 3 & 3 & 2 & 3 & 3 & . & 1 & 1 & 3 & 2 & 3 \\
\hline $\begin{array}{l}\text { Ketersediaan Bahan } \\
\text { Baku }\end{array}$ & . & 2 & & 1 & 1 & . & . & . & 1 & 1 & . & 1 & . & 2 \\
\hline $\begin{array}{l}\text { Telenik dan Sarara } \\
\text { Pengodhan }\end{array}$ & - & 2 & 2 & & . & . & . & . & . & . & . & 3 & . & 1 \\
\hline $\begin{array}{l}\text { Pengembanagan } \\
\text { Vararasiproduk }\end{array}$ & & 3 & . & - & & 2 & 3 & 1 & 1 & 2 & . & 3 & 2 & 2 \\
\hline Unur Simpan Produk & . & 1 & . & . & 2 & & 3 & 2 & . & . & . & 3 & . & 1 \\
\hline $\begin{array}{l}\text { PengemansanPackagin } \\
g\end{array}$ & $\mathrm{n}$ & 3 & . & . & 2 & 3 & & 1 & 1 & 2 & . & 3 & $\cdot$ & 2 \\
\hline SistemPenasaran & . & 2 &. &. & 2 &. & . & & 1 & 2 &. & 2 & 3 & 3 \\
\hline Pemblkan & . & 1 & 1 &. &. & 1 &. & 1 & &. & . & 1 &. & 1 \\
\hline Tenu Bisisis & & 3 & 2 & 1 & 1 &. & 1 & 2 & . & & . &. & 1 & 2 \\
\hline $\begin{array}{l}\text { Responsibilitias } \\
\text { Linghungan }\end{array}$ & 2 & . & . & . & . & . & . & . & . & . & & 1 & . & 2 \\
\hline Ketengagkerjan & $\cdot$ & 2 & 2 & 3 & 3 & 2 & 3 & $\cdot$ & 1 & 1 & 2 & &. & 3 \\
\hline Periminan Lsaha & 2 & 3 &. &. & 1 & $\cdot$ & 1 & 3 &. & 3 & 2 & 1 & &. \\
\hline Peningktatan Onset & 1 & 3 & 1 & 2 & 2 & 1 & 3 & 2 & . & 2 & 2 & 3 & . & \\
\hline
\end{tabular}

\begin{tabular}{cc}
\multicolumn{2}{c}{ Description } \\
\hline Score & A direct influence between factors \\
\hline 0 & there are no direct influence \\
3 & his influence is very strong \\
2 & its influence is \\
Source & minor effect \\
\hline
\end{tabular}


Table 2 Summary of Variables that Affect

\begin{tabular}{lr}
\hline A Global Power & Rated Power \\
\hline Capital & 1,92 \\
Increase In Turnover & 1,50 \\
Business Licensing & 1,49 \\
Employment & 1,44 \\
The Development Of A Variety Of Products & 1,40 \\
Packaging & 1,19 \\
The Marketing System & 1,05 \\
Shelf Life Of The Product & 0,87 \\
Business Meeting & 0,87 \\
Accessibility Infrastructure & 0,57 \\
The Availability Of Raw Materials & 0,51 \\
Techniques and Means of the Processing & 0,50 \\
Bookkeeping & 0,46 \\
Responsibility Environment & 0,25 \\
\hline
\end{tabular}

Each quadrant is associated with specific characteristics of the variables. Quadrant I is a region of variable drive (driving). In this system tdak there is a variable drive. Quadrant II is the region of the control variables (leverage), which is characterized by the influence and also dependence. Some of the variables in this quadrant can be classified as a strong variable. In this system that includes variable input is the capital and the development of a variety of products. Quadrant III is a region of variable output (output), which are highly dependent and only little influence. Variables including the variable out put this is the technique of processing means, the availability of raw materials, employment, turnover, packaging, shelf life, business meeting. Quadrant IV is a region of variable marginal (marginal), this group will be directly excluded from the analysis.

In the left upper quadrant (Quadrant I) is a factor that gives a high influence on the performance of the system with its low dependence on the inter-relatedness of factors. The factors contained in this quadrant is used as a determining factor in the system studied. The factors that are in quadrant II is the factor that gives a high influence on the performance of the system. But will have dependencies between the factors that high, so it is used as a link (stakes) in the system, these variables is the capital and the development of a variety of products.

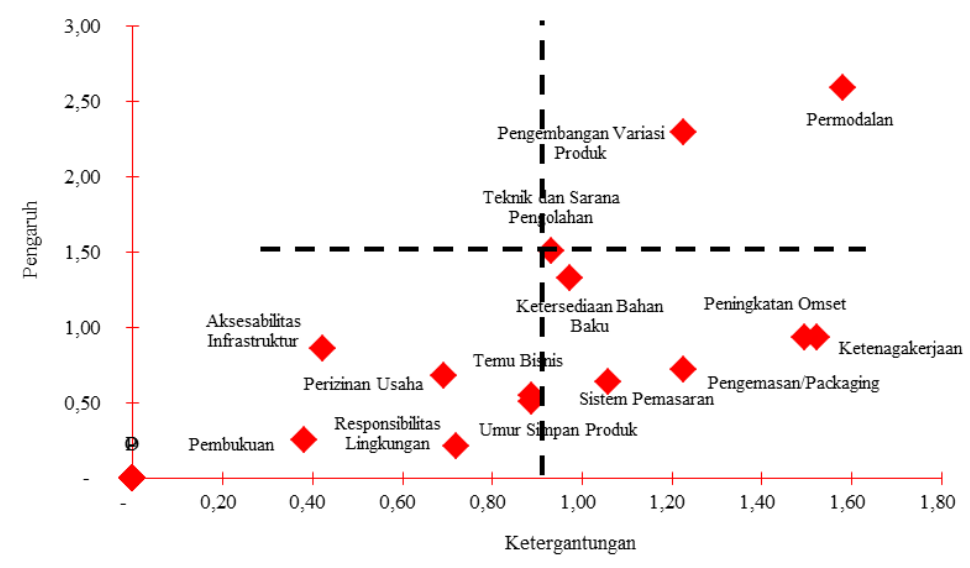

Figure 2 Level of importance of the Influential Factors on the System 
The constraints of capital is the main problem because they still lack a support system. Although capital UMKM has many banks are already making a program for UMKM but in fact a lot of things that become a barrier to get to the UMKM who need it, so that it becomes ineffective in its accomplishment. So can solve the problem of capital, it is very necessary to a financial institution that has a commitment in capital and the development of UMKM themselves.

Permodaln UMKM can be obtained from a variety of loans, such as loans from the bank. However, due to various constraints or reasons, there are still many UMKM do not use the credit from the bank, but they are more than happy to borrow to rentener (bonded labor). With the state it is then the interest expense to be borne by UMKM will be more severe, given the level of interest charged from bonded labor is very high, which ultimately lead to new problems. These problems can come from both internal and external. Internal concerns the characteristics of UMKM, while the external concerns of the system of credit in the bank.

On the contrary granting of credit banking consider the concept $5 \mathrm{C}$, among others, character, capacity, capital, collateral and condition of economic. So in the lending bank will review the similarity of the concepts $5 \mathrm{C}$ with the filing of the credit business. Here there are some criteria of UMKM that are not in accordance with the $5 \mathrm{C}$, the most striking is the capacity and collateral. Capacity to be obstacles because capital UMKM are relatively small, this is because a bank wants payment on time. It is assumed with the small capital of a business then the level pedapatannya the smaller of the accumulation of debt, so the risk of default even greater. But in fact, UMKM have the risk of default is small. Then is a eligible collateral in this case is the presence or absence of collateral or a guarantee of UMKM in credit lending. Collateral is almost the same function with terms of capital, namely as a safety if the event of default by the customer. Obviously this becomes obstacles by UMKM because the average capital used UMKM is the capital of its own, therefore it is the individual who must provide collateral itself. It is becoming an interesting phenomenon to be discussed, where the default risk of small inversely proportional to the difficulty of the credit provided by the banking (Warjiyo 2005).

According to Warjiyo (2005), defalt risk UMKM are relatively small and the potential to get financing from banks. But the reality is the reason of the difficulty of the granting of credit by banks until today is the high credit risk of the financing, so the impact of the precariousness of the procedure and the relatively high level of interest given by the banking sector.

Quadrant lower right (Quadrant III) has the influence of low on system performance and a high dependence on the inter-relatedness of factors, so be output in the system. The factors of the output is affected by the key factors that affect the development of management of the factors that are in Quadrant I and II. Factors that go in Quadrant III is the increase in output, employment, marketing system, packaging and raw material availability.

With the problems that exist in Quadrant III, such as reduced network marketing, the limitations of raw materials and the existence of less labor support, then with the help of both capital from the Government or state-owned enterprises then it will be very help UMKM in the face of the existing problems and the. According to the Bonita (2013), in the presence of sufficient capital, the UMKM can do marketing of their products with how to rent a shop or store in a place that is more strategic, and of course, the UMKM can produce with plenty of capacity and marketed to other areas so that their products can be more known by the public at large.

The lower left quadrant (quadrant IV) has a low influence on system performance and a low dependence on inter-factor relatedness. The factors found in this quadrant IV are infrastructure accessibility, venture authorisation, bookkeeping. According to Kharisma and 
Wibowo (2019) planning and budgeting play an important role in achieving development goals on a national and regional scale, especially fundamental development such as infrastructure. The development planning document through the medium-term production Framework approach presents the relationship between policy priorities and available budgets. Development planning documents are implemented annually through the Regional Development Budget through the public Production Management approach. Consistency between the two documents is necessary to achieve the purpose of development.

Therefore, in developing the industry in South Tangerang need the creation of added value based on an idea that was born from the creativity of human resources and utilization of science-based, including cultural heritage and technology. Key resource is creativity (creativity) which is defined as the capacity factor or driving force for innovation and the work of different (out of the box). The creative economy puts creativity and knowledge as a key asset in moving the economy.

The creative economy should be a top priority in south Tangerang. Works of art, food, animation, fashion and other sub-sectors, is a potential sourced from creative ideas from the community. On the basis of the department of tourism initiated form an institution of the creative economy that is able to boost all the potential in all aspects of the creative economy. In the development of the creative sector all potential such as culinary, fashion, information technology, arts and other is expected to be making maximum efforts to boost the activities of the creative economy in South Tangerang.

\section{CONCLUSION}

1. Based on biographical data UMKM new (start-up), the average does not have a legal, as a result access to capital to be difficult.

2. The variable that has the dependencies between the factors that high, so it is used as a link (stakes) in the system (input), these variables is the capital and the development of a variety of products.

3. Variables including the variable out put this is the technique of processing means, the availability of raw materials, employment, turnover, packaging, shelf life, business meeting.

\section{REFERENCES}

Anonim. 2008. Rencana Pengembangan Ekonomi Kreatif 2009-2025. Departemen Perdagangan Republik Indonesia. Depdag RI, 2008.

Bonita F. 2013. Strategi Pengembangan Industri Kecil Kerajinan Batik di Kota Semarang. Economics Development Analysis Journal. EDAJ 2 (3) (2013):234-245.

Bourgeois R. 2004. Participatory Prospective Analysis: Exploring and Anticipating Challenges with Stakeholder. CAPSA Monograph No. 46. the United Nation.

[BPS] Badan Pusat Statistik. 2017. Sensus Ekonomi 2016.

[BPS] Badan Pusat Statistik. 2017. Kota Tangerang Selatan Dalam Angka 2016. Canton J. 2007. The Extreme Future: the Top Trends That will Reshape the Word in the Next 20 Years. A Plume Boo Business. 
Eriyatno. 1999. Ilmu Sistem Maningkatkan Mutu dan Efektifitas Manajemen. IPB Press. Bogor. Godet M and F Roubelat. 1998. Creating the future: the use and misuse of scenarios. Long Range Planning, 29(2): 164-171, 1996.

Hartrisari. 2007. Sistem Dinamik Konsep Sistem dan Pemodelan untuk Industri dan Lingkungan. Southeast Asian Regional Center for Tropical Biology (BIOTROP) Bogor.

Kharisma B, K Wibowo. 2019. Consistency of Planning and Budgeting of Basic infrastructure in West Java Province. Economics Development Analysis Journal. Economics Development Analysis Journal 8 (1) (2019):65-80.

Marimin. 2004. Teknik dan Aplikasi Pengambilan Keputusan Kriteria Majemuk. Grasindo: Jakarta.

Nazir M.2005. Metode Penelitian. Jakarta. Ghalia Indonesia.

Pangestu ME. 2008. Pengembangan Industri Kreatif Menuju Visi Ekonomi Kreatif Indonesia 2025. Departemen Perdagangan Republik Indonesia.

Pusparini H. 2011. Strategi Pengembangan Industri Kreatif Di Sumatra Barat. Pasca Sarjana Universitas Andalas Padang.

Salusu J. 2000. Pengambilan Keputusan Stratejik. Jakarta: Gramedia.

[UU] Undang-Undang No. 20 Tahun 2008 tentang Usaha Mikro Kecil dan Menengah.

Warjiyo P. 2005. Buletin Ekonomi Moneter dan Perbankan, Maret 2005"default risk dan penjaminan kredit UKM"

Winarno B. 1990. Seratus Kiat Jurus Sukses Kaum Bisnis 2. Grafiti. Jakarta 